\title{
Detachment and motility of surface-associated ciliates at increased flow velocities
}

\author{
Ute Risse-Buhl $^{1,2, *}$, Anja Scherwass ${ }^{2}$, Annette Schlüssel $^{2}$, Hartmut Arndt $^{2}$, \\ Sandra Kröwer ${ }^{1}$, Kirsten Küsel ${ }^{1}$ \\ ${ }^{1}$ Limnology Research Group, Institute of Ecology, Friedrich Schiller University Jena, Dornburger Strasse 159, \\ 07743 Jena, Germany \\ ${ }^{2}$ Department of General Ecology and Limnology, Zoological Institute, University of Cologne, 50931 Cologne, Germany
}

\begin{abstract}
Though seldom investigated, the microcurrent environment may form a significant part of the ecological niche of protists in stream biofilms. We investigated whether specific morphological features and feeding modes of ciliates are advantageous for a delayed detachment at increased flow velocities. Three sessile filter feeders (Vorticella, Carchesium and Campanella spp.), 6 vagile filter feeders (Aspidisca, Euplotes, Holosticha, Stylonychia, Cinetochilum and Cyclidium spp.) and 2 vagile gulper feeders (Chilodonella and Litonotus spp.) were studied. A rotating disk on top of the culture medium generated different flow velocities in Petri dishes. All tested sessile species stayed attached at the fastest investigated flow velocity $\left(4100 \mu \mathrm{m} \mathrm{s}^{-1}\right)$. Vorticella convallaria (Peritrichia) remained about $45 \%$ of the observed time in a contracted state at $>2600 \mu \mathrm{m} \mathrm{s}^{-1}$. Hence, filtration activity of sessile ciliates seemed to be inhibited at high flow velocities. Among the vagile filter feeders, flattened species which extended more than $60 \mu \mathrm{m}$ into the water column and round species showed the lowest resistance to high flow velocities. Only the vagile flattened gulper feeder Chilodonella uncinata (Phyllopharyngia) withstood flow velocities $\geq 2600 \mu \mathrm{m} \mathrm{s}^{-1}$. All studied vagile species (except the seldom-creeping Cyclidium glaucoma) had a higher displacement rate and showed a positive rheotactic creeping behavior between 300 and $1100 \mu \mathrm{m} \mathrm{s}^{-1}$. Thus, dispersion and positive rheotaxis might allow vagile species to colonize more favorable habitats and balance the drift caused by the unidirectional flow of water.
\end{abstract}

KEY WORDS: Ciliate morphotypes $\cdot$ Biofilm $\cdot$ Flow velocity $\cdot$ Boundary layer $\cdot$ Motility $\cdot$ Rheotaxis

\section{INTRODUCTION}

In stream ecosystems that are characterized by the unidirectional flow of water, the majority of bacteria and protists are associated with stationary surfaces (Geesey et al. 1978, Schwoerbel 1994). The boundary layer at the liquid-solid interface is thought to be an important habitat for lotic microbial and invertebrate communities (Ambühl 1959, Schwoerbel 1994). Although the flow velocity decreases exponentially at the interface, the laminar flow at the surface can become turbulent due to surface roughness (Oertel et al. 2001). Even within a biofilm, the microcurrent in voids can reach up to $90 \%$ of the flow velocity measured $2 \mathrm{~mm}$ above the biofilm surface (de Beer et al. 1994, Stoodley et al. 1994). When the microcurrent increases above certain values, heterotrophic flagellates are detached from artificial surfaces (Willkomm et al. 2007). Thus, specific morphological features of surface-associated organisms might be advantageous at high flow velocities to avoid drift.

Biofilm-associated ciliates contribute to the carbon and energy transfer from bacteria and protists to the meio- and macrofauna. Due to their grazing activity, ciliates keep bacteria in the exponential growth phase which stimulates the decomposition of coarse particulate organic matter such as leaf litter in streams (Ribblett et al. 2005). Increased flow velocities are positively correlated to clearance and feeding rates of sedimentary ciliates (Shimeta et al. 2001). Further, flow 
velocity influences the distribution of ciliates according to their feeding modes. In stream biofilms, vagile flattened gulper feeding ciliates dominate at high flow velocities, whereas vagile round and flattened filter feeding ciliates dominate at slow flow velocities (RisseBuhl \& Küsel 2009). However, detachment of ciliates from surface with respect to different morphotypes and their feeding modes at increased flow velocities has rarely been studied.

Motility of ciliates on surfaces can be described as random walk in the absence of external stimuli (Berg 1993). Under still water conditions, ciliates increase the probability of feeding in the inhabited food patch by lowering their walking speed and increasing the frequency of tumbling (Jonsson \& Johansson 1997, Stock et al. 1997, Lawrence \& Snyder 1998, Fenchel \& Blackburn 1999). The directed movement towards an external stimulus is ensured by lowering the frequency of tumbling and increasing walking time and speed. According to the flow direction, ciliates show either positive or negative rheotactic responses (Jennings 1906, Ricci et al. 1992, Ricci et al. 1999). Ciliate motility can be affected by increased flow velocities leading to inhibition of food uptake or to dispersion out of the preferred food patch. Thus, it is important to study the motility pattern of ciliates at different flow velocities to evaluate the role of microcurrents in the aquatic microbial food web of lotic habitats (Fenchel \& Blackburn 1999, Fenchel 2004).

The objective of the present study was to investigate detachment and motility of 11 ciliate species with different morphological features at increased flow velocities. We hypothesized that (1) vagile flattened gulper feeders with cilia reduced to one cell side are not detached at high flow velocities, and (2) increased flow velocities induce positive rheotaxis and larger displacement rates of all vagile ciliates.

\section{MATERIALS AND METHODS}

Ciliate cultures. Ten ciliate species with different morphological features and attachment mechanisms (see Table 1) were isolated or enriched from the Ilm stream in Thuringia, Germany. In the enrichment cultures, flagellates or other ciliates of minor abundance $(<20 \%)$ were present. One sessile colony forming ciliate species, Campanella umbellaria (Peritrichia), was isolated from a small pond at Cologne. C. umbellaria developed 1, 4 or 8 heads, whereas Carchesium polypinum (Peritrichia) developed 7 to 44 heads. Batch cultures of ciliates were kept at $20 \pm 2^{\circ} \mathrm{C}$ in Volvic water (Le Dû-Delepierre et al. 1996) with a sterilized rice grain. The chlorophyte Chlorogonium sp. (freshwater soil extract medium; kindly provided by K. Eisler, Insti- tute of Zoology, University of Tübingen) was used as an additional food source (added twice a week) for cultures of Euplotes patella (Hypotrichia), Stylonychia pustulata (Stichotrichia) and Holosticha monilata (Stichotrichia). Litonotus cygnus (Haptoria) was kept in mixed cultures with Vorticella convallaria (Peritrichia) and Cinetochilum margaritaceum (Hymenostomatia).

Microscale flow velocity. Petri dishes $(\varnothing=13.5 \mathrm{~cm})$ were filled with $75 \mathrm{ml}$ water to reach a water column height of $0.5 \mathrm{~cm}$. Regulated by the current supply of a motor, a rotating disk on top of the water or culture medium generated the flow velocity (Willkomm et al. 2007). The current supply of the motor was adjusted to $2.5,6,8,14,16$ and $24 \mathrm{~V}$. The Petri dishes were directly placed under an inverse microscope (Axiovert S100, Zeiss). Flow velocities along the diameter of the Petri dish (distance from Petri dish centre $=4,5$ and $6 \mathrm{~cm}$ ) were measured at an elevation of $20 \mu \mathrm{m}$ above the surface. Furthermore, flow velocity profiles were measured at 6 different elevations between 5 and $200 \mu \mathrm{m}$ above the Petri dish surface at a distance of $4 \mathrm{~cm}$ from the Petri dish centre. The highest elevation was chosen because the studied vagile ciliates extended less than $200 \mu \mathrm{m}$ into the water column. For this purpose, the speed of 5 to 10 neutrally buoyant hollow glass spheres (diameter $=10 \mu \mathrm{m}$; kindly provided by $\mathrm{H}$. Røy, Max Planck Institute for Marine Microbiology, Bremen, Germany; Røy 2003) was estimated from video image sequences of 25 frames s ${ }^{-1}$.

Measurements revealed that the flow velocity in the Petri dishes increased towards the outer edge, especially at the 2 highest flow velocities. Flow velocity changes were small between 4 and $5 \mathrm{~cm}$ distance from the Petri dish centre. In this area, deviations of the projected flow velocities of 300,400, 700, 1100, 2600 and $4100 \mathrm{~m} \mathrm{~s}^{-1}$ ranged from $280-420,340-540,380-780$, $700-1900,2200-3500$ and $4000-5300 \mu \mathrm{m} \mathrm{s}^{-1}$, respectively. To ensure that higher flow velocities in outer areas did not affect the motility of ciliates, motility tracks were studied in the area between 4 and $5 \mathrm{~cm}$ from the Petri dish centre that corresponded to video sequences within 2 min after start of the experiment. Hereafter, flow velocities referred to in the text correspond to $20 \mu \mathrm{m}$ elevation above the Petri dish surface. The flow velocity increased exponentially between 5 and $200 \mu \mathrm{m}$ elevation above the Petri dish surface and was 1.1 to 7.1 times higher at $200 \mu \mathrm{m}$ than at $5 \mu \mathrm{m}$ elevation (Fig. 1).

Experimental setup. Ciliate cultures $(75 \mathrm{ml})$ were filled in Petri dishes. The total observation area ranged from a distance of 4 to $6 \mathrm{~cm}$ from the Petri dish centre. All observations started at a distance of $4.5 \mathrm{~cm}$ from the Petri dish centre. The 3 sessile species (Peritrichia) were pregrown on glass slides fixed with Baysilone (silicone paste, VWR) in Petri dishes. Ciliate cultures of vagile 


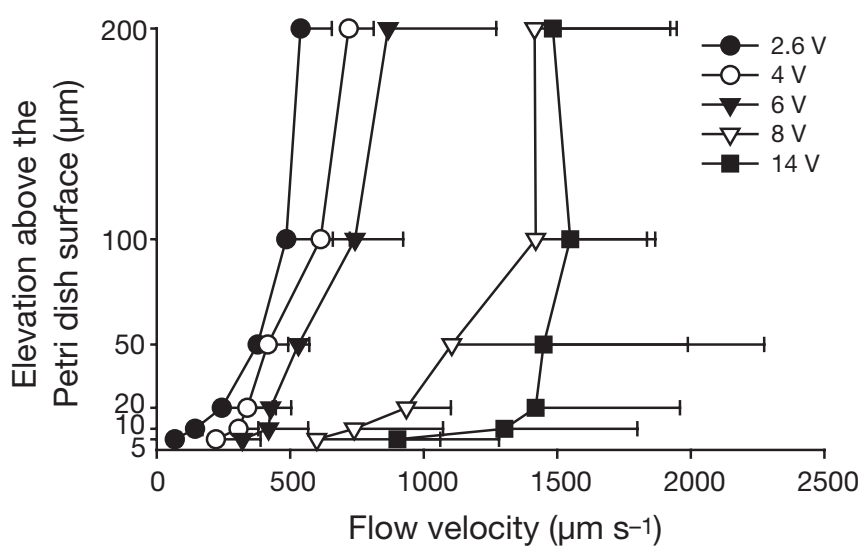

Fig. 1. Flow velocities ( $\mu \mathrm{m} \mathrm{s}^{-1}$ ) measured within 5 to $200 \mu \mathrm{m}$ elevation above the surface of the Petri dish microcosms at increasing speed of the rotating disk (V) (mean $\pm \mathrm{SD}, \mathrm{n}=5$ ). The speed of the disk was linked with a near-surface velocity at a distance of $20 \mu \mathrm{m}$ above the surface that is experienced by most surface-associated ciliates: $2.5,4,6,8,14,16$ and $24 \mathrm{~V}$ corresponds to $300,400,500,700,1100,2600$ and $4100 \mu \mathrm{m} \mathrm{s}^{-1}$

species were filled into the Petri dishes unfiltered to avoid food limitation during the experiment. A pre-incubation of at least $12 \mathrm{~h}$ served as time for recovery and adaptation to the environmental changes, allowing the comparative study of different ciliate species.

The flow velocity was increased stepwise at intervals of $300 \mu \mathrm{m} \mathrm{s}^{-1}$ (near disk velocity) every $5 \mathrm{~s}$ for vagile species and every 2 min for sessile species until the target velocity was reached. The ciliates were observed alive for a maximum of $5 \mathrm{~min}$ (vagile species) or $10 \mathrm{~min}$ (sessile species). To minimize artifacts due to adaptation of ciliates to the flow velocity environment (Machemer 1988), at least 30 min relaxation time was guaranteed between experiments. Ciliate cells from 3 to 8 different Petri dishes served as independent replicates. If separate sessile ciliate cells were recorded in one microscopic observation field, they served as an independent replicate as well. Cells were observed using phase contrast at $25 \times$ magnification, except for Cinetochilum margaritaceum and Cyclidium glaucoma which were observed at $40 \times$ and $100 \times$ magnification, respectively. All observations were recorded on videotapes (S-VHS).

The time until detachment, motility of vagile ciliates and contraction behavior of sessile ciliates was studied at average flow velocities of 300, 1100, 2600 and $4100 \mu \mathrm{m} \mathrm{s}^{-1}$, which corresponded to flow velocities at the rotating disk of $0.1,0.4,0.8$ and $1.2 \mathrm{~m} \mathrm{~s}^{-1}$ (Willkomm et al. 2007). In addition, intermediate flow velocities of 400, 500 and $700 \mu \mathrm{m} \mathrm{s}^{-1}$ were used for 4 vagile species that could not withstand velocities $\geq 1100 \mu \mathrm{m} \mathrm{s}^{-1}$. Still water conditions served as controls. The percentage of cells remaining attached to the sur- face at the aforementioned flow velocities compared to still water conditions represented the species capacity to withstand detachment. To check behavioral adaptations of ciliates, the elevation of cells above the surface of 4 species was measured during the flow velocity treatment of $300 \mu \mathrm{m} \mathrm{s}^{-1}$ using the calibrated fine drive of the microscope.

Analysis of ciliate behavior. In case of vagile ciliates, a video sequence of 1 min was analyzed; alternatively, when ciliates detached earlier, the entire sequence was used. During the observation time, the number of side stepping reactions (SSR) (Ricci et al. 1992, Barbanera et al. 2000) was counted as a measure of cell orientation of Litonotus cygnus, Euplotes patella, Stylonychia pustulata, and Holosticha monilata. SSRs are characterized by a fast backwards movement followed by a reorientation of the cell (Jennings 1906). A grid (spot size of one square $100 \times 100 \mu \mathrm{m}$ ) was placed on the screen and the direction of cell movement was recorded by means of spot changes towards, away from or rectangular to the direction of the flow. With these data the relative contribution of each of the 4 directions was calculated where the sum of all spot changes was set at $100 \%$. The net distance moved in a given time period was measured to calculate the displacement rate. Displacement rate and length:width ratio of ciliate tracks demonstrate the effectiveness of a track in displacing the organism in space. Video sequences of the sessile Vorticella convallaria were examined for the number of contractions within the maximal observation time (10 $\mathrm{min})$. The time needed for cell and stalk extension after contraction was measured with video frame-by-frame analysis (at 25 frames $\mathrm{s}^{-1}$ ). The duration of the extension was estimated by dividing the number of frames it took the ciliate to extend cell and stalk by the number of frames per second. One contraction of a single $V$. convallaria cell observed during $0-2,4-6$ and 8-10 min after the start of the experiment was used to measure the extension time.

Data analysis. The independent sample $t$-test was used to observe significant differences of the examined behavioral parameters between flow velocity treatments (SPSS 15.0). Data were not transformed. Pearson correlation coefficients were calculated to test the elevation of cells above the surface and time until detachment at certain flow velocities.

\section{RESULTS}

\section{Detachment of vagile ciliates}

Chilodonella uncinata was the only vagile ciliate that could withstand the fastest tested flow velocity of $4100 \mathrm{~m} \mathrm{~s}^{-1}$ (Fig. 2A). However, 13 and $75 \%$ of C. unci- 


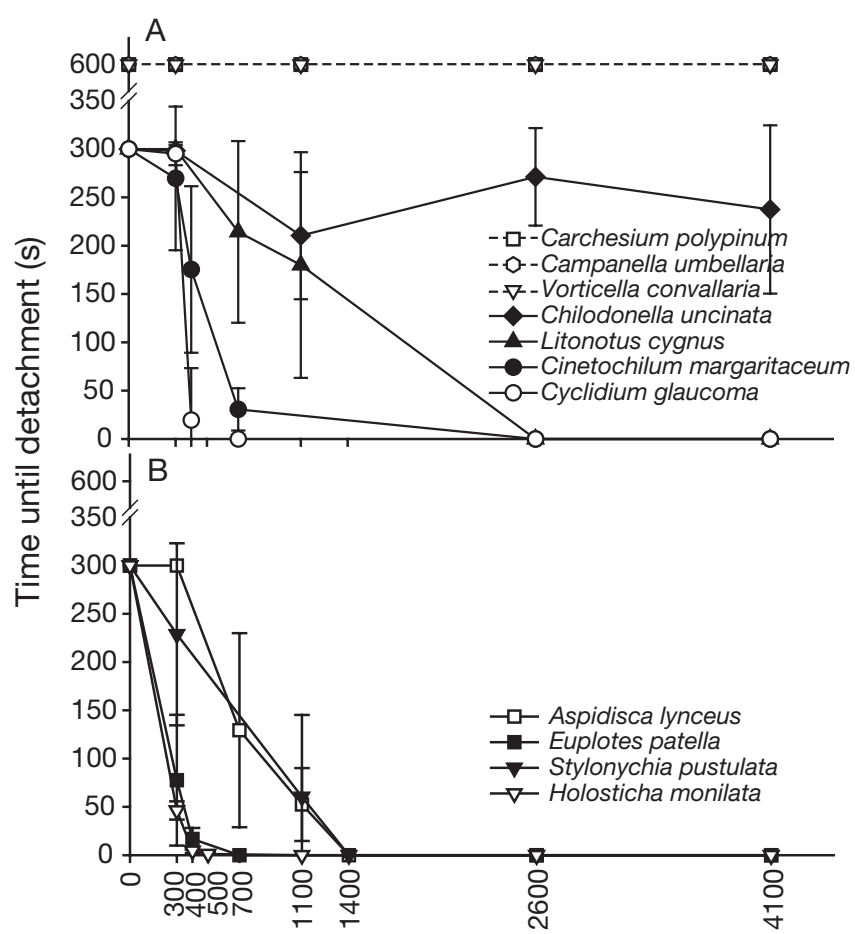

Flow velocity $20 \mu \mathrm{m}$ above the surface $\left(\mu \mathrm{m} \mathrm{s} \mathrm{s}^{-1}\right)$

Fig. 2. Time (s) until detachment of investigated ciliate species at different flow velocity treatments $\left(\mu \mathrm{m} \mathrm{s}^{-1}\right)$ (mean \pm $\mathrm{SD}, \mathrm{n}=4$ to 16). (A) Sessile filter feeders: Carchesium polypinum, Campanella umbellaria, Vorticella convallaria; vagile flattened gulper feeders: Chilodonella uncinata, Litonotus cygnus, Cinetochilum margaritaceum; and vagile round filter feeder: Cyclidium glaucoma. (B) Vagile flattened filter feeders: Aspidisca lynceus, Euplotes patella, Stylonychia pustulata and Holosticha monilata. The maximum observation period was 5 and $10 \mathrm{~min}$ for vagile and sessile ciliates, respectively

nata cells detached at 2600 and $4100 \mu \mathrm{m} \mathrm{s}^{-1}$ (Table 1), respectively. Irrespective of flow velocity, cells of $C$. uncinata crept to the outer region of the Petri dish, and detachment times displayed in Fig. 2A represent the time the cells stayed in the projected flow velocity area, i.e. in the observation area between 4 and $6 \mathrm{~cm}$ from the Petri dish centre. At $1100 \mu \mathrm{m} \mathrm{s}^{-1}$, the flattened Litonotus cygnus stayed attached to the surface longer than Stylonychia pustulata and Aspidisca lynceus. Nonetheless, the majority of L. Cygnus (58\%) and $A$. lynceus $(75 \%)$ cells detached at flow velocities $\geq 700 \mu \mathrm{m} \mathrm{s}^{-1}$ (Table 1). Species which extended more than $60 \mu \mathrm{m}$ above the surface, such as Stylonychia pustulata (50\%), Holosticha monilata (100\%) and Euplotes patella (100\%) detached at $300 \mu \mathrm{m} \mathrm{s} \mathrm{s}^{-1}$ (Fig. 2B, Table 1). The elevation of cells above the surface of morphological similar species (i.e. vagile flattened filter feeders of the Hypotrichia and Stichotrichia) was correlated with time until detachment; these parameters were negatively correlated at flow velocities of 300
$\left(\mathrm{R}^{2}=-0.996, \mathrm{p}<0.01, \mathrm{n}=4\right), 700\left(\mathrm{R}^{2}=-0.961, \mathrm{p}<0.05\right.$, $\mathrm{n}=4)$ and $1100 \mu \mathrm{m} \mathrm{s}^{-1}\left(\mathrm{R}^{2}=-0.803, \mathrm{p}=0.197, \mathrm{n}=4\right)$, indicating that vagile flattened filter feeders with a lower elevation above the surface have a higher resistance against flow velocity. Interestingly, $H$. monilata and E. patella successively detached and reattached to the surface of the Petri dish during the observation time. The vagile flattened Cinetochilum margaritaceum and the vagile round Cyclidium glaucoma (Fig. 2A) stayed attached for $>260 \mathrm{~s}$ at $300 \mu \mathrm{m} \mathrm{s} \mathrm{s}^{-1}$. Despite the low elevation, all Cinetochilum margaritaceum cells detached at $700 \mu \mathrm{m} \mathrm{s}^{-1}$ and all Cyclidium glaucoma cells detached at $400 \mu \mathrm{m} \mathrm{s}^{-1}$ (Table 1). When all studied vagile flattened species were included in the correlation analysis, elevation of cells above the surface and time until detachment were negatively correlated at $300 \mu \mathrm{m} \mathrm{s}^{-1}\left(\mathrm{R}^{2}=-0.937, \mathrm{p}=0.002, \mathrm{n}=7\right)$, $700 \mu \mathrm{m} \mathrm{s}^{-1}\left(\mathrm{R}^{2}=-0.627, \mathrm{p}=0.132, \mathrm{n}=7\right)$ and $1100 \mu \mathrm{m}$ $\mathrm{s}^{-1}\left(\mathrm{R}^{2}=-0.497, \mathrm{p}=0.257, \mathrm{n}=7\right)$. No flow velocity profiles at near-surface velocities $>1100 \mu \mathrm{m} \mathrm{s}^{-1}$ were measured since all but one studied vagile species were detached at this flow velocity.
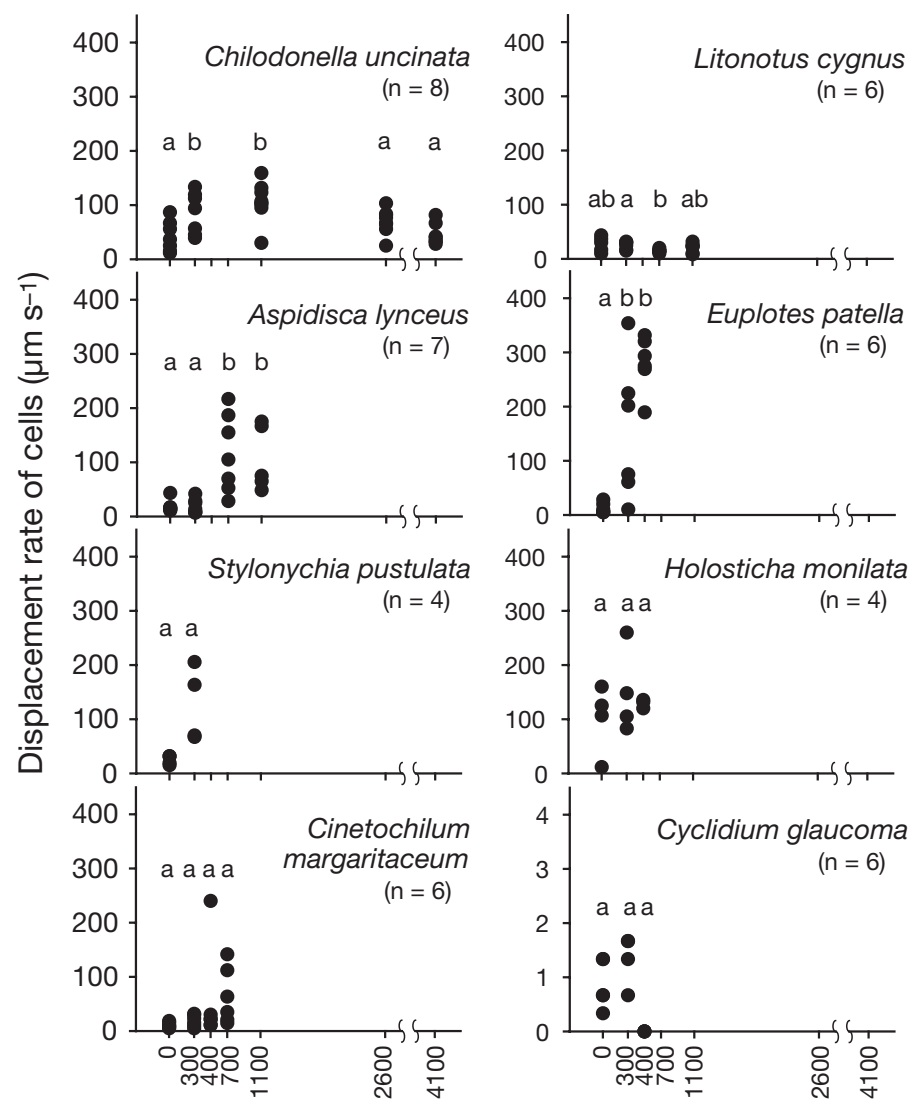

Flow velocity $20 \mu \mathrm{m}$ above the surface $\left(\mu \mathrm{m} \mathrm{s} \mathrm{s}^{-1}\right)$

Fig. 3. Displacement rate under different flow velocity treatments of ciliate cells that detached. ${ }^{\text {abc: }}$ different letters indicate significant differences between flow velocity treatments ( $t$-test, $\mathrm{p}<0.05$ ) 


\section{Behavioral responses of vagile ciliates}

The displacement rate of Chilodonella uncinata was significantly higher at $300(\mathrm{p}=0.033, \mathrm{n}=8)$ and $1100 \mathrm{\mu m} \mathrm{s}^{-1}(\mathrm{p}=0.003, \mathrm{n}=8)$, but not at $2600(\mathrm{p}=0.060$, $\mathrm{n}=8)$ and $4100 \mu \mathrm{m} \mathrm{s}^{-1}(\mathrm{p}=0.768, \mathrm{n}=8)$, compared to still water conditions (Fig. 3). The number of spot changes of $C$. uncinata were significantly lower at $4100 \mu \mathrm{m} \mathrm{s}^{-1}(\mathrm{p}=0.022, \mathrm{n}=8)$ compared to still water conditions (Fig. 4). Flow velocity did not affect the displacement rate of Litonotus cygnus (Fig. 3), but cells contracted more often (11 to $13 \mathrm{~min}^{-1}$ ) at all tested flow velocities compared to still water conditions $\left(8 \mathrm{~min}^{-1}\right)$. In contrast, vagile species that walk with ventral cirri along the surface, such as Euplotes patella, Stylonychia pustulata and Holosticha monilata, showed higher displacement rates and higher numbers of spot changes at 300 to $1100 \mu \mathrm{m} \mathrm{s}^{-1}$ (Figs. 3 \& 4). Both parameters varied greatly, displaying large differences between single cells. SSR of E. patella ( $<<0.01, \mathrm{n}=6), S$. pustulata $(\mathrm{p}=$ $0.001, \mathrm{n}=4)$ and $H$. monilata $(\mathrm{p}<0.05, \mathrm{n}=4)$ increased as well at flow velocities $\geq 300 \mu \mathrm{m} \mathrm{s}^{-1}$ compared to still water conditions (Table 2). The elevation of E. patella above the surface was significantly reduced ( $\mathrm{p}=0.002$, $\mathrm{n}=5)$ at $300 \mu \mathrm{m} \mathrm{s}^{-1}$ (Fig. 5). Displacement rates $(\mathrm{p}<$ $0.05, \mathrm{n}=7$ ) and number of spot changes $(\mathrm{p}>0.05, \mathrm{n}=7$ ) of Aspidisca lynceus were higher at 700 and $1100 \mu \mathrm{m}$ $\mathrm{s}^{-1}$ compared to still water conditions and $300 \mu \mathrm{m} \mathrm{s}^{-1}$.

Table 1. Characteristics of investigated ciliate species and relative percentage of cells that remained at the surface at different flow velocities measured $20 \mu \mathrm{m}$ above the surface $\left(\mu \mathrm{m} \mathrm{s}^{-1}\right)$ during a 5 min (vagile species) or 10 min (sessile species) observation period (values in parentheses represent number of observed cells). S: sessile; CS: contractile stalk; AS: acontractile stalk; VF: vagile flattened; VR: vagile round; GF: gulper feeder; FF: filter feeder; nd: not determined

\begin{tabular}{|c|c|c|c|c|c|c|c|c|c|c|}
\hline \multirow[t]{2}{*}{ Taxon } & \multirow{2}{*}{$\begin{array}{l}\text { Morphology } \\
\text { feeding } \\
\text { mode }\end{array}$} & \multirow{2}{*}{$\begin{array}{c}\text { Length } \times \\
\text { width } \\
(\mu \mathrm{m}, \mathrm{n}>8)\end{array}$} & \multirow{2}{*}{$\begin{array}{l}\text { Elevation } \\
\text { above surface } \\
(\mu \mathrm{m}, \mathrm{n}>8)\end{array}$} & \multicolumn{7}{|c|}{$\begin{array}{c}\% \text { cells remaining at surface } \\
\text { Flow velocity }\left(\mu \mathrm{m} \mathrm{s}^{-1}\right)\end{array}$} \\
\hline & & & & 0 & 300 & 400 & 600 & 1100 & 2600 & 4100 \\
\hline \multicolumn{11}{|l|}{ Phyllopharyngia } \\
\hline Chilodonella uncinata & $\mathrm{VF}, \mathrm{GF}$ & $30-50 \times 15-25$ & $23-39$ & $100(8)$ & $100(11)$ & nd & nd & $100(10)$ & $87(8)$ & $25(8)$ \\
\hline \multicolumn{11}{|l|}{ Haptoria } \\
\hline Litonotus cygnus & VF, GF & $165-230 \times 27-31$ & $35-53$ & $100(6)$ & $100(5)$ & nd & $42(12)$ & $25(12)$ & nd & nd \\
\hline \multicolumn{11}{|l|}{ Hypotrichia } \\
\hline Aspidisca lynceus & $\mathrm{VF}, \mathrm{FF}$ & $43-51 \times 31-39$ & $27-41$ & $100(8)$ & $100(8)$ & nd & $25(8)$ & $0(7)$ & nd & nd \\
\hline Euplotes patella & $\mathrm{VF}, \mathrm{FF}$ & $78-110 \times 47-78$ & $50-105$ & $100(8)$ & $0(12)$ & $0(17)$ & $0(6)$ & nd & nd & nd \\
\hline \multicolumn{11}{|l|}{ Stichotrichia } \\
\hline Stylonychia pustulata & $\mathrm{VF}, \mathrm{FF}$ & $75-130 \times 40-60$ & $31-72$ & $100(7)$ & $50(8)$ & nd & nd & $0(8)$ & nd & nd \\
\hline Holosticha monilata & $\mathrm{VF}, \mathrm{FF}$ & $100-170 \times 43-63$ & $82-138$ & $100(4)$ & $0(4)$ & $0(10)$ & nd & $0(4)$ & nd & nd \\
\hline \multicolumn{11}{|l|}{ Hymenostomatia } \\
\hline Cinetochilum margaritaceum & $m \mathrm{VF}, \mathrm{FF}$ & $34-45 \times 28-34$ & $18-35$ & $100(7)$ & $83(6) 1$ & $12(7)$ & $0(10)$ & nd & nd & nd \\
\hline Cyclidium glaucoma & VR, FF & $17-22 \times 8-13$ & $6-8$ & $100(6)$ & $83(6)$ & $0(10)$ & nd & nd & nd & nd \\
\hline \multicolumn{11}{|l|}{ Peritrichia } \\
\hline Carchesium polypinum & $\mathrm{S}, \mathrm{CS}, \mathrm{FF}$ & $50-100 \times 40-70$ & $1645-2300$ & $100(4)$ & $100(4)$ & nd & nd & $100(4)$ & $100(4)$ & $100(4)$ \\
\hline Campanella umbellaria & $\mathrm{S}, \mathrm{AS}, \mathrm{FF}$ & $135-160 \times 90-120$ & $0270-1340$ & $100(4)$ & $100(4)$ & nd & nd & $100(4)$ & $100(4)$ & $100(4)$ \\
\hline Vorticella convallaria & $\mathrm{S}, \mathrm{CS}, \mathrm{FF}$ & $42-85 \times 34-62$ & $100-386$ & $100(16)$ & $100(16)$ & ) nd & nd & $100(16)$ & $100(16)$ & $100(16)$ \\
\hline
\end{tabular}

Table 2. Number of side stepping reactions per minute of 4 tested ciliate species shown as median and quartile range (25 to $75 \%$ )

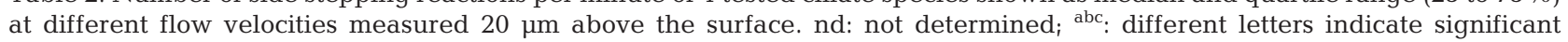
differences between flow velocity treatments $(t$-test, $\mathrm{p}<0.05)$

\begin{tabular}{|c|c|c|c|c|c|c|}
\hline & \multicolumn{6}{|c|}{ Flow velocity $\left(\mu \mathrm{m} \mathrm{s}^{-1}\right)$} \\
\hline & 0 & 300 & 400 & 500 & 700 & 1100 \\
\hline $\begin{array}{l}\text { Litonotus cygnus } \\
(\mathrm{n}=6)\end{array}$ & $\begin{array}{c}8.0^{\mathrm{a}} \\
6.0-10.8\end{array}$ & $\begin{array}{c}13.0^{\mathrm{a}} \\
10.0-13.0\end{array}$ & nd & nd & $\begin{array}{c}11.8^{\mathrm{a}} \\
8.6-14.5\end{array}$ & $\begin{array}{c}11.5^{\mathrm{a}} \\
11.1-14.5\end{array}$ \\
\hline $\begin{array}{l}\text { Euplotes patella } \\
(\mathrm{n}=6)\end{array}$ & $\begin{array}{c}5.4^{\mathrm{a}} \\
2.5-6.8\end{array}$ & $\begin{array}{c}13.0^{\mathrm{b}} \\
10.2-18.8\end{array}$ & $\begin{array}{c}25.2^{\mathrm{c}} \\
21.1-31.8\end{array}$ & nd & nd & nd \\
\hline $\begin{array}{l}\text { Stylonychia pustulata } \\
(\mathrm{n}=4)\end{array}$ & $\begin{array}{c}9.6^{\mathrm{a}} \\
5.9-14.8\end{array}$ & $\begin{array}{c}37.0^{\mathrm{b}} \\
34.7-39.0\end{array}$ & nd & nd & nd & $\begin{array}{c}116.4^{\mathrm{c}} \\
101.3-134.3\end{array}$ \\
\hline $\begin{array}{l}\text { Holosticha monilata } \\
(\mathrm{n}=4)\end{array}$ & $\begin{array}{c}19.3^{\mathrm{a}} \\
14.5-24.4\end{array}$ & $\begin{array}{c}22.7^{\mathrm{a}} \\
18.8-27.5\end{array}$ & $\begin{array}{c}28.4^{\mathrm{a}} \\
19.2-48.2\end{array}$ & $\begin{array}{c}41.7^{\mathrm{a}} \\
20.8-62.5\end{array}$ & nd & nd \\
\hline
\end{tabular}




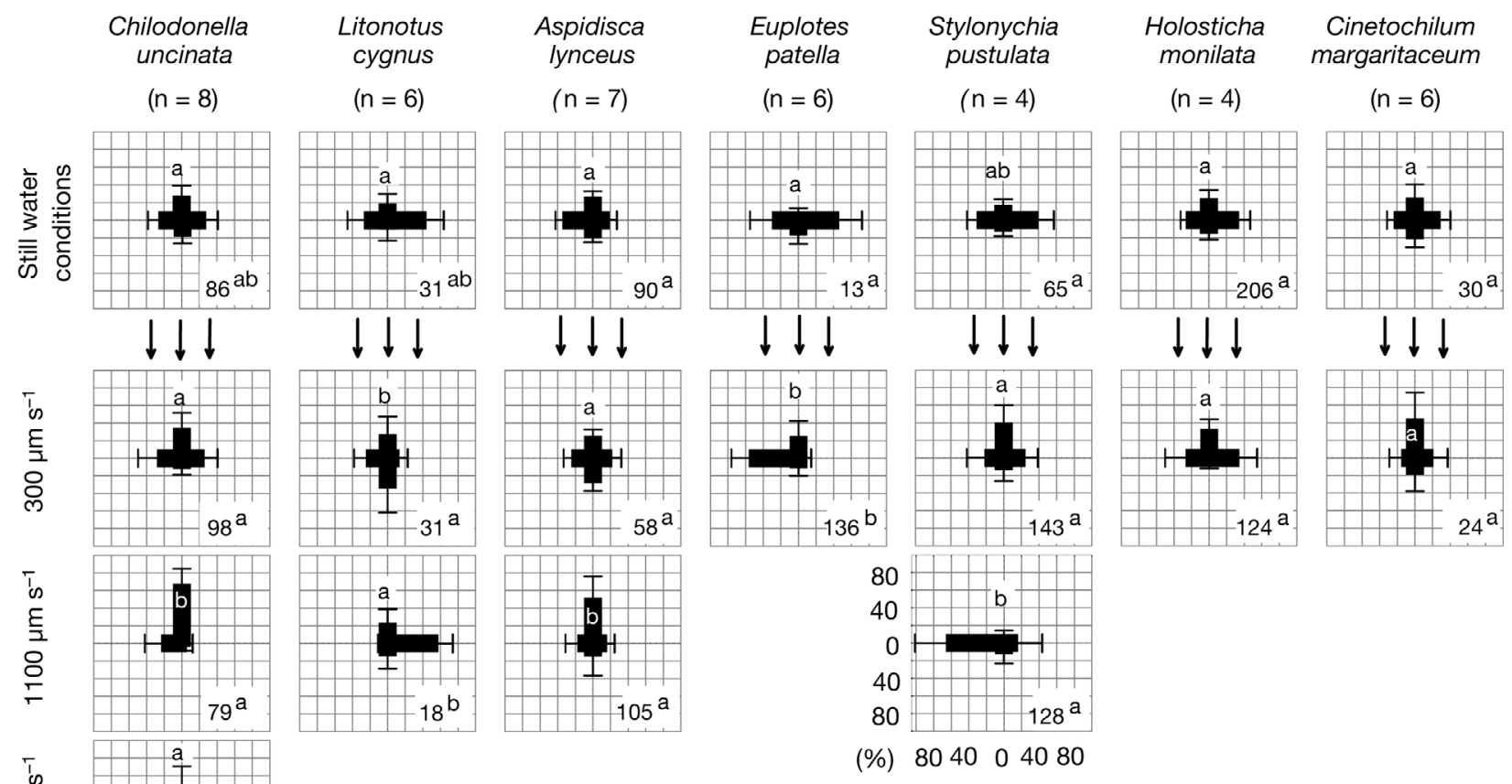

Fig. 4. Chilodonella uncinata, Litonotus cygnus, Aspidisca lynceus, Euplotes patella, Stylonychia pustulata, Holosticha monilata and Cinetochilum margaritaceum. Creeping direction of ciliate cells in response to different flow velocities shown as percentage distribution (mean $\pm \mathrm{SD}$ ) and total number of spot changes $\mathrm{min}^{-1}$ (numbers in the lower right corner of graphs [median]). Cyclidium glaucoma is not included in the figure since the species rarely crept at the Petri dish surface. Arrows: flow

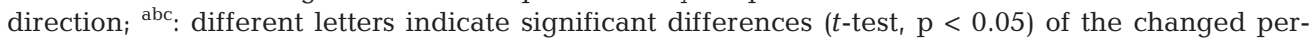
centage of spots against the flow direction (upwards bars) and of the spot changes between flow velocity treatments

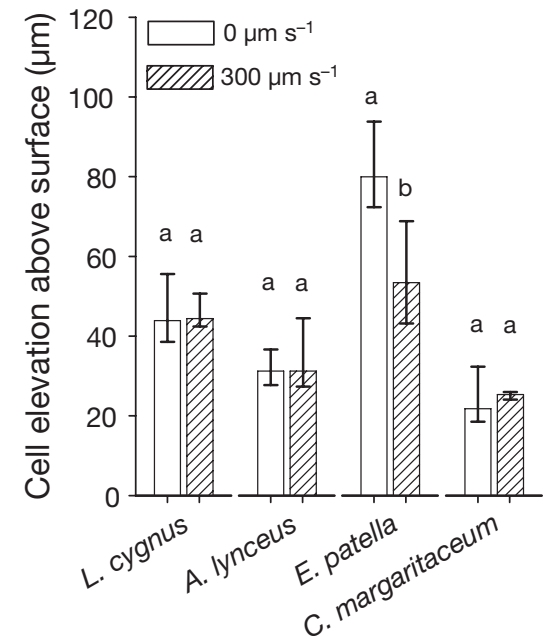

Fig. 5. Litonotus cygnus, Aspidisca lynceus, Euplotes patella and Cinetochilum margaritaceum. Elevation $(\mu \mathrm{m})$ of cells above the surface observed during still water conditions and $300 \mu \mathrm{m} \mathrm{s}^{-1}$. Box: median; error bars: 25 th and 75 th percentiles; ${ }^{\mathrm{ab}}$ different letters indicate significant differences between flow velocity treatments ( $t$-test, $\mathrm{p}<0.05, \mathrm{n}=5$ )
The behavioral responses of the dorso-ventrally flattened Cinetochilum margaritaceum and round Cyclidium glaucoma were not altered at $300 \mu \mathrm{m} \mathrm{s}^{-1}$. Cinetochilum margaritaceum showed similar responses to vagile flattened species that walk with cirri, displaying a larger displacement rate $(p=0.052$, $\mathrm{n}=6)$ at $700 \mu \mathrm{m} \mathrm{s}^{-1}$ compared to still water conditions (Fig. 3). Cyclidium glaucoma stayed at the surface and rarely moved at still water conditions, remaining in one $100 \times 100 \mu \mathrm{m}$ spot for 150 of $300 \mathrm{~s}$. During flow velocity treatments, many of the observed cells of Cyclidium glaucoma oriented their anterior-posterior axis in the flow direction. Length:width ratios of all observed ciliate tracks increased due to flow velocity impact from a mean of $1.9-3.1$ to $4.9-14.0$, except tracks of the rarely creeping Cyclidium glaucoma.

A positive rheotactic response showed Chilodonella uncinata, Litonotus cygnus, Euplotes patella, Stylonychia pustulata, Holosticha monilata and Cinetochilum margaritaceum at $300 \mu \mathrm{m} \mathrm{s}^{-1}$ with 25 to $45 \%$ of spots changed against the flow direction (Fig. 4). At $1100 \mu \mathrm{m}$ $\mathrm{s}^{-1}$, significantly more spots were changed against the 


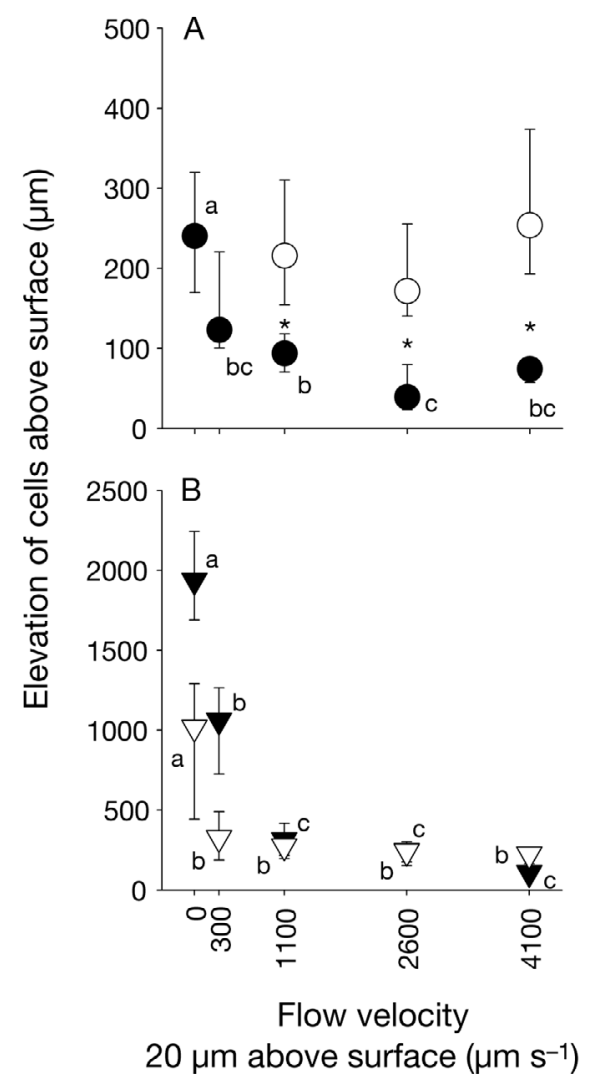

Fig. 6. Vorticella convallaria, Carchesium polypinum and Campanella umbellaria. Elevation $(\mu \mathrm{m})$ of cells above the surface observed during different flow velocity treatments (symbol: median, error bars: 25th and 75th percentiles) for (A) $V$. convallaria during $(\bullet)$ and after $(\mathrm{O})$ flow velocity treatment; (B) C. polypinum ( $\mathbf{\nabla})$; and C. umbellaria $(\nabla) .{ }^{\text {abc: }}$ different letters indicate significant differences between flow velocity treatments ( $t$-test, $\mathrm{p}<0.05, \mathrm{n}=6$ to 21 [ $V$. convallaria], $\mathrm{n}=4$ [C. polypinum, C. umbellaria]); Asterisks in (A) indicate significant differences between flow velocity treatment and recovery for $V$. convallaria ( $t$-test, $\mathrm{p}<0.05, \mathrm{n}=4$ to 16 )

flow direction by Chilodonella uncinata $(68 \%, \mathrm{p}=$ $0.000, \mathrm{n}=8$ ) and Aspidisca lynceus (58\%, $\mathrm{p}=0.021, \mathrm{n}=$ 7). Chilodonella uncinata, L. cygnus, S. pustulata, $H$. monilata (data not shown) and E. patella were sidetracked and crept mainly at a $90^{\circ}$ angle in relation to the flow direction at the corresponding highest flow velocity of each species. The main movement of cells was directed towards the outer region of the Petri dish, except in L. cygnus, where a greater percentage of spot changes were directed towards the inner region of the Petri dish.

\section{Detachment and contraction of sessile ciliates}

The sessile ciliates Carchesium polypinum, Campanella umbellaria and Vorticella convallaria (all Peri-
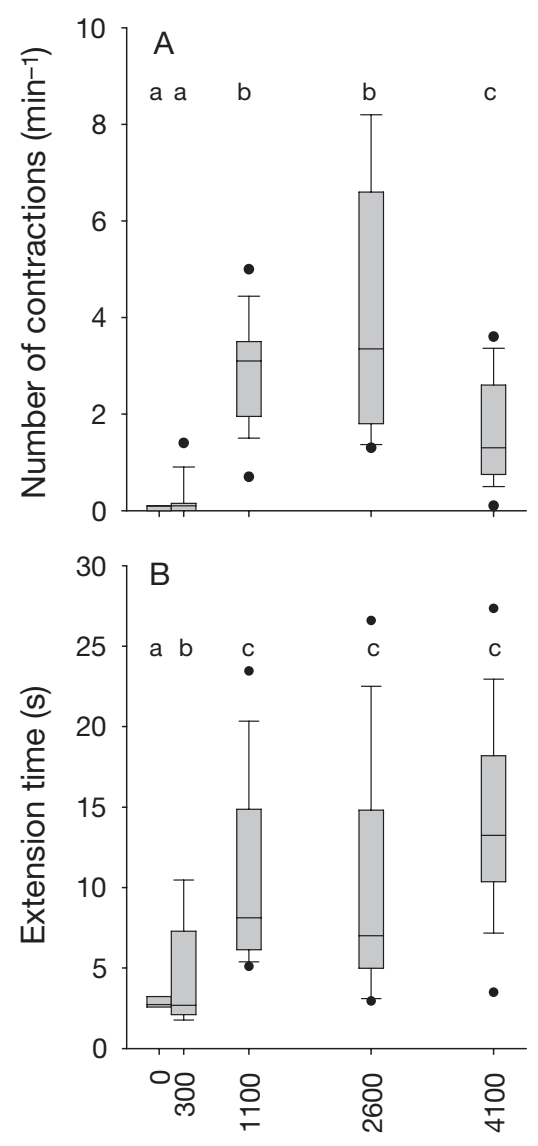

Flow velocity $20 \mu \mathrm{m}$ above surface $\left(\mu \mathrm{m} \mathrm{s} \mathrm{s}^{-1}\right)$

Fig. 7. Vorticella convallaria. (A) Number of contractions $\left(\mathrm{min}^{-1}\right)$ and (B) extension time (s) at different flow velocity treatments. Box: median; error bars: 25th and 75th percentiles; dots: 99th percentiles; ${ }^{\text {abc: }}$ different letters indicate significant differences between flow velocity treatments $(t-$ test, $\mathrm{p}<0.05, \mathrm{n}=9$ to 17 )

trichia) stayed attached at all tested flow velocities during the 10 min observation period (Fig. 2A). Even if the velocity was increased from 0 to $4100 \mu \mathrm{m} \mathrm{s}^{-1}$ within $30 \mathrm{~s}$, stalks did not detach from the surface. All studied Peritrichia species were lying on the surface, resulting in a significant lower elevation above the surface during flow velocity treatments compared to still water conditions (Fig. 6). V. convallaria cells regained their former elevation after the flow ceased. In still water conditions and $300 \mu \mathrm{m} \mathrm{s}^{-1}, V$. convallaria contracted $0.05 \mathrm{~min}^{-1}$, and the extension of the cell body and stalk lasted 2.7 s (Fig. 7). Higher flow velocities caused significantly longer extension times, with a mean of $11.6 \mathrm{~s}$ ( $\mathrm{p}<0.05, \mathrm{n}=10$ to 16 ), and contractions occurred 60 times more often ( $\mathrm{p}<0.001, \mathrm{n}=10$ to 17 ) compared to still water conditions and $300 \mu \mathrm{m} \mathrm{s}^{-1}$. Extension times at the beginning and end of the observation period were not significantly different. 


\section{DISCUSSION}

\section{Flow velocity conditions and food supply at surfaces}

In the $5 \mathrm{~mm}$ water column of the Petri dish, laminar flow occurs in the lower $700 \mu \mathrm{m}$ from the dish surface at a disk flow velocity of $0.3 \mathrm{~m} \mathrm{~s}^{-1}$ (Willkomm et al. 2007). However, it is not easy to define the exact flow velocity at the position of a single surface-associated protist cell in rotating water. Thus, we will not compare absolute values of flow velocities in the Petri dish with velocities in streams; instead we will focus on the comparison of the behavior of the ciliate species tested. Species with a low elevation above the surface $(<40 \mu \mathrm{m})$ such as Aspidisca lynceus had a higher resistance to higher flow velocities than morphological similar species with a higher elevation $(50$ to $140 \mu \mathrm{m})$ into the water column such as Holosticha monilata and Euplotes patella. Thus, the elevation of cells above a surface was a critical factor in the resistance to high flow velocities. Additionally, small species like A. lynceus and Cyclidium glaucoma (Table 1) withstood 3 and 10 times higher flow velocities, respectively, when cells stayed behind biofilm microstructures (U. Risse-Buhl pers. obs.). The flow velocity is highly reduced in the vicinity of bacterial microcolonies or behind snail shells (de Beer et al. 1994, Willkomm et al. 2007). Therefore, a small cell size might be advantageous in the exploitation of biofilm micro-niches.

Surface roughness increases the retention of organic matter (Huettel et al. 1996), which can serve as a food source for biofilm-associated ciliates. High flow velocities near biofilms and in biofilm voids minimize the thickness of the diffusion boundary layer and enhance nutrient and gas exchange (de Beer et al. 1994, 1996). More ciliates, sessile as well as vagile, colonize the nodes of Ranunculus penicillatus than the leaves that are exposed to high flow velocities of the stream (Baldock et al. 1983). Nevertheless, it is advantageous for ciliates to colonize biofilms at faster bulk flow velocities because prey advection is enhanced (Hunt \& Parry 1998, Shimeta et al. 2001) and bacteria are kept in a productive state due to enhanced nutrient transport from the water column into the biofilm (Kaplan \& Newbold 2003). Surface topology appears to affect the biofilm colonization by protists, because protist cells accumulate behind biofilm microstructures at high bulk flow velocities to avoid potential detachment (A. Schlüssel \& H. Arndt pers. obs.).

\section{Detachment of different ciliate morphotypes at increased flow velocities}

The 3 sessile Peritrichia species stayed firmly attached to the surface at high flow velocities. Peritrichia are known to withstand storm flows, although stalks show traces of abrasion after $12 \mathrm{~h}$ (Blenkinsopp \& Lock 1994). However, the abundance of Peritrichia was negligible in initial biofilms grown at high flow velocities in flow channel experiments and in the Ilm stream (Risse-Buhl \& Küsel 2009). In experimental flow channels, sessile species of the genera Carchesium and Vorticella were less abundant in the flowing compared to the stagnant treatment (Bick \& Schmerenbeck 1971). Thus, attachment and stalk anchorage on virgin surfaces appears to be inhibited at high flow velocities. In the present study, attached Vorticella convallaria (Peritrichia) remained about $45 \%$ of the observed time in a contracted state at the 2 highest flow velocities (>2600 $\mathrm{mm} \mathrm{s}^{-1}$ ) tested. The cell and stalk contraction resulted in a lower filtration activity. Under conditions of inhibited food uptake, swarmers, the motile stage of the otherwise sessile Peritrichia, are formed that can be dispersed to find more suitable habitats. Increased numbers of Peritrichia heads are found at the beginning of high water situations in the River Rhine, indicating disruption of sessile ciliates due to changing conditions of the flow regime (Scherwass \& Arndt 2005). On the other hand, tidal currents increase the clearance rate of sedimentary ciliates (Shimeta et al. 2001). Thus, attached filter feeders might contribute to organic carbon channeling from the water column into stream biofilms only up to certain flow velocities.

Besides cell attachment by stalks, the flattened cell shape of vagile gulper feeders also facilitated a high resistance to detachment at high flow velocities. Chilodonella uncinata dominates biofilms at higher flow velocities in the River Rhine (Schmitz 1985) and showed a similar resistance to high flow velocities in the present study. Morphologically similar species such as Trithigmostoma cucullulus (Phyllopharyngia) and Litonotus lamella (Haptoria) tolerated higher flow velocities in biofilms of the Ilm stream (Risse-Buhl \& Küsel 2009). In contrast, the vagile flattened filter feeder Aspidisca lynceus, which similarly extended up to $40 \mu \mathrm{m}$ into the water column, could not withstand flow velocities $>1400 \mu \mathrm{m} \mathrm{s}^{-1}$. Despite the higher resistance to higher flow velocities of $C$. uncinata compared to A. lynceus, both species showed similar motility changes under the impact of increased flow velocities. Thus, the ability to cling to surfaces seemed to be influenced by specific morphological characteristics. The vagile flattened gulper feeder $C$. uncinata might avoid detachment either by creating a vacuum on the ventral side or by special cilia that produce a kind of adhesive substance. This strategy might enable vagile flattened species to survive in their preferred patch during the frequently occurring flood events in streams. Thus, they probably contribute to initial biofilm communities after flood events. 
Vagile flattened and round filter feeders showed a lower resistance to higher flow velocities in the present study. Food limitation, which increases the propensity to leave the surface (Jonsson \& Johansson 1997), can be neglected as a reason for this low resistance, since a bacterial biofilm was developed at the Petri dish surface during the adaptation time $(\geq 12 \mathrm{~h})$. Benthic vagile flattened filter feeders are resuspended from surficial marine sediments by accelerating tidal flows (Shimeta \& Sisson 1999, Shimeta et al. 2002). In contrast to vagile flattened gulper feeders, the movement of vagile flattened filter feeders with cirri enlarges the distance between cell and surface, which might cause cell detachment at low flow velocities.

\section{Behavioral changes of vagile ciliates at increased flow velocities}

The behavior of ciliates comprises not just cell motility, but adaptive behavior to given environmental conditions (Fenchel 1987, Ricci 1989), i.e. the ability to position themselves within the survival limits of their own biology (Meyer \& Guillot 1990). The vagile flattened filter feeder Euplotes sp. (Hypotrichia) has a higher probability of feeding in an inhabited food patch by lowering the walking speed and increasing the frequency of tumbling (Jonsson \& Johansson 1997, Stock et al. 1997, Lawrence \& Snyder 1998, Fenchel \& Blackburn 1999). Actually, all studied vagile ciliates except the seldom creeping Cyclidium glaucoma showed distinct changes in their motility under the impact of flow velocity. The vagile flattened filter feeders E. patella and Holosticha monilata, which extended up to $140 \mu \mathrm{m}$ into the water column, repeatedly attached to the surface and resumed walking after detachment. Despite the lower elevation above the surface of E. patella at $300 \mu \mathrm{m} \mathrm{s}^{-1}$ compared to still water conditions, cells had a lower resistance to higher flow velocities than the similarly sized Stylonychia pustulata. Euplotes sp. efficiently uses tidal currents to disperse and exploit patchily distributed food sources (Jonsson \& Johansson 1997). This strategy might also be important in streams where differences in flow velocity around stones cause a patchy distribution of food sources.

The straightened tracks and higher displacement rates at 300 to $1100 \mu \mathrm{m} \mathrm{s}^{-1}$ might enable ciliates to rapidly colonize adjacent patches protected against high flow velocities, i.e. eddy waters behind invertebrate cages (Stiller 1957) and biofilm microstructures (Willkomm et al. 2007). These eddy water zones are accumulation zones (Silvester \& Sleigh 1985) where food sources for ciliates might also accumulate. Thus, a high dispersion at increased flow velocity enables vagile flattened ciliates to rapidly find undepleted food patches. Larger sized flagellates (length 20 to $30 \mu \mathrm{m}$, elevation $\sim 10 \mu \mathrm{m}$ ) search for and accumulate in areas of slow flow velocities behind biofilm microstructures (Willkomm et al. 2007), where they slow down or even stop moving (A. Schlüssel \& H. Arndt pers. obs.). In the present study, when exposed to high flow velocities, the displacement rate of Aspidisca lynceus behind microstructures was low and cells stayed in the zone of reduced flow velocity (U. Risse-Buhl pers. obs.).

A positive rheotactic response was observed for almost all studied ciliates between 300 and $1100 \mu \mathrm{m}$ $\mathrm{s}^{-1}$. Due to the orientation of the cells' anterior-posterior axis in the flow direction, the usual orientation of the cilia is maintained (Jennings 1906). Positive rheotaxis in Uronychia setigera (Hypotrichia) enables the cells to resist the tidal water currents and to remain in their preferred patch (Ricci et al. 1999). Losses due to downstream drift in streams might be balanced by a positive rheotaxis. Stichotrichia and Hypotrichia ensured movement towards the flow direction with the help of numerous SSR. Mechanoreceptors of ciliates respond to the hydromechanical signal of increased flow velocity by depolarizing the cell membrane (Goertz 1982, Machemer 2003), which leads to an alteration of creeping velocity and direction of the ciliate cell. Sensing of the hydromechanical signal of flow velocity fluctuations is important for swimming ciliates to recognize prey (postitive rheotaxis towards moving prey, Jakobsen et al. 2006) or to escape predators (escape jumping, Jakobsen 2001, 2002). To efficiently escape filter feeding currents of predators, the jump direction needs to be perpendicular to the produced flow lines. Hence the movement perpendicular to the flow direction of 5 vagile ciliates observed in the present study either might enable the ciliate cells to escape high flow velocity environments or is just a passive sidetracking caused by shear that acts on surfaceassociated ciliate cells.

In conclusion, flow velocity seems to be an important abiotic parameter that influenced detachment and distribution patterns of surface-associated ciliates. Minor fluctuations of flow velocity caused the detachment of vagile round and flattened filter feeders from surfaces. Only one vagile flattened gulper feeder and all sessile filter feeders could stand the highest flow velocities. At increased flow velocities, the studied vagile ciliates increased the displacement rate and oriented their creeping towards the flow direction (positive rheotaxis). Further studies are needed to estimate the limits of flow velocity at which protists remain actively feeding and contribute to the carbon channeling through the microbial food web in biofilms.

Acknowledgements. We sincerely thank M. Willkomm, H. Norf, M. Reiche and B. Spänhoff for support; G. Becker and M. Mutz for helpful advice in analyzing motility pattern; and 
W. Schönborn for helpful discussions. This work was supported by grants from the German Science Foundation to U.R.B. (GRK 266/3) and H.A. (WE 3545/3-1).

\section{LITERATURE CITED}

Ambühl H (1959) Die Bedeutung der Strömung als ökologischer Faktor. Schweiz Z Hydrol 21:133-264

Baldock BM, Baker JH, Sleigh MA (1983) Abundance and productivity of protozoa in chalk streams. Holarct Ecol 6: 238-246

Barbanera F, Erra F, Ricci N (2000) The effects of heating on the behaviour of Oxytricha bifaria (Ciliophora, Hypotrichida). Can J Zool 78:484-494

Berg HC (1993) Random walks in biology, 2nd edn. Princeton University Press, Princeton, NJ

Bick H, Schmerenbeck W (1971) Vergleichende Untersuchungen des Peptonabbaus und der damit verknüpften Ciliatenbesiedlung in strömenden und stagnierenden Modellgewässern. Hydrobiologia 37:409-446

Blenkinsopp SA, Lock MA (1994) The impact of storm-flow on river biofilm architecture. J Phycol 30:807-818

de Beer D, Stoodley P, Lewandowski Z (1994) Liquid flow in heterogeneous biofilms. Biotechnol Bioeng 44:636-641

de Beer D, Stoodley P, Lewandowski Z (1996) Liquid flow and mass transport in heterogeneous biofilms. Water Res 30: 2761-2765

Fenchel T (1987) Ecology of protozoa: the biology of freeliving phagotrophic protists, 1st edn. Springer, Berlin

Fenchel T (2004) Orientation in two dimensions: chemosensory motile behaviour of Euplotes vannus. Eur J Protistol 40:49-55

Fenchel T, Blackburn N (1999) Motile chemosensory behavior of phagotrophic protists: mechanisms for and efficiency in congregating at food patches. Protist 150:325-336

Geesey GG, Mutch R, Costerton JW, Green RB (1978) Sessile bacteria: an important component of the microbial population in small mountain streams. Limnol Oceanogr 23: 1214-1223

Goertz HD (1982) The behavior and fine-structure of the dorsal bristles of Euplotes minuta, Euplotes aediculatus, and Stylonychia mytilus (Ciliata, Hypotrichida). J Protozool 29:353-359

Huettel M, Ziebis W, Forster S (1996) Flow-induced uptake of particulate matter in permeable sediments. Limnol Oceanogr 41:309-322

> Hunt AP, Parry JD (1998) The effect of substratum roughness and river flow rate on the development of a freshwater biofilm community. Biofouling 12:287-303

Jakobsen HH (2001) Escape response of planktonic protists to fluid mechanical signals. Mar Ecol Prog Ser 214:67-78

Jakobsen HH (2002) Escape of protists in predator-generated feeding currents. Aquat Microb Ecol 26:271-281

> Jakobsen HH, Everett LM, Strom SL (2006) Hydromechanical signaling between the ciliate Mesodinium pulex and motile protist prey. Aquat Microb Ecol 44:197-206

Jennings HS (1906) Behavior of the lower organisms, 1st edn. Columbia University Press, New York

Jonsson PR, Johansson M (1997) Swimming behavior, patch exploitation and dispersal capacity of a marine benthic ciliate in flume flow. J Exp Mar Biol Ecol 215:135-153

Kaplan LA, Newbold JD (2003) The role of monomers in stream ecosystem metabolism. In: Findlay SEG, Sinsabaugh RL (eds) Aquatic ecosystems: interactivity of dissolved organic matter. Academic Press, Amsterdam, p 97-119

Lawrence JR, Snyder RA (1998) Feeding behavior and graz- ing impacts of a Euplotes sp. on attached bacteria. Can J Microbiol 44:623-629

Le Dû-Delepierrel A, Persoone G, Groliére CA (1996) A new low cost microbiotest with the freshwater ciliate protozoan Spirostomum ambiguum. Hydrobiologia 325:121-130

> Machemer H (1988) Das Experiment: können Einzeller lernen? Prüfung am Habituationsexperiment. Biol Unserer Zeit 18:122-127

Machemer H (2003) Behavior of protozoa. In: Hausmann K, Hülsmann N, Radek R (eds) Protistology. E. Schweizerbart'sche Verlagsbuchhandlung, Stuttgart, p 288-291

Meyer JA, Guillot A (1990) From animals to animates: everything you wanted to know about the simulation of adaptive behavior. Ecole Normale Supérieure, Paris

Oertel H, Etling D, Müller U, Riedel U, Warnatz J (2001) Prandtl: Führer durch die Strömungslehre, 10th edn. Friedrich Vieweg \& Sohn, Braunschweig/Wiesbaden

Ribblett SG, Palmer MA, Coats DW (2005) The importance of bacterivorous protists in the decomposition of stream leaf litter. Freshw Biol 50:516-526

Ricci N (1989) Microhabitats of ciliates: specific adaptations to different substrates. Limnol Oceanogr 34:1089-1097

> Ricci N, Erra F, Russo A, Banchetti R (1992) The interface between air and water: a perturbation source eliciting adaptive behavior in ciliates. J Protozool 39:521-525

Ricci N, Cionini K, Banchetti R, Erra F (1999) Rheotaxis in Uronychia setigera (Ciliata, Hypotrichida). J Eukaryot Microbiol 46:268-277

Risse-Buhl U, Küsel K (2009) Colonization dynamics of biofilm-associated ciliate morphotypes at different flow velocities. Eur J Protistol 45:64-76

Røy H (2003) Dynamic structure and function of the diffusive boundary layer at the seafloor. PhD dissertation, University of Bremen

Scherwass A, Arndt H (2005) Structure, dynamics and control of the ciliate fauna in the potamoplankton of the River Rhine. Arch Hydrobiol 164:287-307

Schmitz M (1985) Ökologische und systematische Untersuchungen an Ciliaten (Protozoa, Ciliophora) des Rheins bei Bonn, BRD. Verh Int Ver Limnol 22:2292-2296

Schwoerbel J (1994) Trophische Interaktionen in Fließgewässern. Limnologica 24:185-194

Shimeta J, Sisson JD (1999) Taxon-specific tidal resuspension of protists into the subtidal benthic boundary layer of a coastal embayment. Mar Ecol Prog Ser 177:51-62

Shimeta J, Starczak VR, Ashiru OM, Zimmer CA (2001) Influences of benthic boundary-layer flow on feeding rates of ciliates and flagellates at the sediment-water interface. Limnol Oceanogr 46:1709-1719

Shimeta J, Amos CL, Beaulieu SE, Ashiru OM (2002) Sequential resuspension of protists by accelerating tidal flow: implications for community structure in the benthic boundary layer. Limnol Oceanogr 47:1152-1164

> Silvester NR, Sleigh MA (1985) The forces on microorganisms at surfaces in flowing water. Freshw Biol 15:433-448

Stiller J (1957) Zur Biologie und Verbreitung der Protozoenund Crustaceenfauna eines Mittelgebirgsbaches in Ungarn. Arch Hydrobiol 53:392-424

Stock C, Krüppel T, Lueken W (1997) Kinesis in Euplotes vannus: ethological and electrophysiological characteristics of chemosensory behavior. J Eukaryot Microbiol 44:427-433

> Stoodley P, de Beer D, Lewandowski Z (1994) Liquid flow in biofilm systems. Appl Environ Microbiol 60:2711-2716

Willkomm M, Schlüssel A, Reiz E, Arndt H (2007) Effects of microcurrents in the boundary layer on the attachment of benthic heterotrophic nanoflagellates. Aquat Microb Ecol 48:169-174 